\title{
Control of runner reed (Phragmites japonicus) in lentic wetlands
}

\author{
Mun Gi Hong ${ }^{1}$, Hyun Jun Park', Bo Eun Nam ${ }^{1}$ and Jae Geun Kim ${ }^{12^{*}}$ (D)
}

\begin{abstract}
In lotic wetlands, runner reed (Phragmites japonicus) plays a role as a pioneer, which helps other plant species to settle by making dense roots trapping floating-sediments. In lentic wetlands, on the other hand, $P$. japonicus could play a role as an invader threatening biodiversity by forming tall and dense stands. To conserve an abandoned paddy terrace in mountainous areas, a habitat of an endangered dragonfly species (Nannophya pygmaea), from the monotypicoccupation by P. japonicus, we applied three kinds of treatment: (1) hand-clipping in 2009, (2) mechanical excavating in 2012, and (3) planting of alternative vegetational unit in 2012. We have monitored vegetation changes in the wetland in 2008 2012 and 2017. Vegetation cover of P. japonicus sharply decreased from 43\% in 2011 to 16\% in 2012 by the mechanical excavation. After 5 years from applying the treatment, Schoenoplectiella mucronata that was utilized in the planting became the predominant species instead of $P$. japonicus and the number of wetland plant species increased from 16 to 25 with the shift in species composition. This study showed the utility of three control methods of $P$. japonicas in a lentic wetland.
\end{abstract}

Keywords: Abandoned paddy field, Abandoned paddy terrace, Mechanical excavation, Physical control, Stolonization

\section{Background}

There are two emergent macrophytes of genus Phragmites (Poaceae) in Northeast Asian countries: common reed (Phragmites australis (Cav.) Trin. ex Steud.) and runner reed (Phragmites japonicus Steud.). It is uneasy to distinguish those species when they are mixed because of their similar appearances (Kim and Kim 2009; Chu et al. 2011; Park et al. 2018). Instead of their outer characteristics, the ecology of those species may be better guides to distinguish them. $P$. australis makes rhizomes and inhabits downstream, estuary, and salt marsh, whereas P. japonicus develops stolons and inhabits upstream and adjacent areas (Chun et al. 1999; Hong et al. 2012; Hong and Kim 2014; Park et al. 2018).

In particular, $P$. japonicus with wide-spreading stolons and dense roots system shows high adaptability in oligotrophic environments such as lotic wetlands in upstream and lentic wetlands in mountainous area (Chun et al. 1999; Asaeda et al. 2009; Park et al. 2018). In lotic wetlands, $P$. japonicus plays a role as a pioneer, which helps other plant species to settle by making dense roots

\footnotetext{
* Correspondence: jaegkim@snu.ac.kr

'Department of Biology Education, Seoul National University, Seoul 08826, Korea

${ }^{2}$ Center for Education Research, Seoul National University, Seoul 08826, Korea
}

trapping floating-sediments (Choe and Kim 1999; Asaeda et al. 2011). In lentic wetlands, on the other hand, $P$. japonicus could play a role as an invader threatening biodiversity by forming tall and dense stands (Byun et al. 2008; Hong et al. 2012).

In this study, we have focused on an abandoned paddy terrace in which an endangered dragonfly species (Nannophya pygmaea Rambur) lives (Yoon et al. 2010, 2011). P. japonicus had invaded from a nearby streamlet and spread out rapidly into the wetland. To conserve the habitat of the endangered dragonfly species, we applied three kinds of treatment ((1) hand-clipping in 2009, (2) mechanical excavating in 2012, and (3) planting of alternative vegetational unit in 2012) into the wetland and have monitored vegetational changes as the results of the treatments. This report provides not only effective treatment plans for P. japonicus in lentic wetlands but also a 10-year monitoring result on the abandoned paddy field which needs to be conserved for an endangered dragonfly species.

\section{Materials and methods \\ Study site}

Our study site is a unit wetland of an abandoned paddy terrace within mountainous areas $\left(35^{\circ} 15^{\prime} 54.13^{\prime \prime} \mathrm{N}, 127^{\circ}\right.$ 
$16^{\prime} 28.11^{\prime \prime}$ ) in South Jeolla Province of South Korea. Although the paddy terrace had been abandoned prior to 2001 because of hard accessibility for agriculture (Hong et al. 2012), it became a natural ecological protection area for the inhabitation of scarlet pygmy dragonfly ( $N$. pygmaea) which was designated as an endangered species in Korea (Kim et al. 2010; Yoon et al. 2010, 2011). We began to monitor the study site from 2008 because of the occupation by $P$. japonicus. More information on the study site in detail is available in Hong et al. (2012).

\section{Treatment plans}

As a preliminary treatment for the control, (1) some of mature stands of $P$. japonicus in the study site were clipped in August 2009. After verifying the effect of the preliminary treatment via the monitoring in September 2011, (2) the rest of mature stands including below-ground parts within shallow areas were mechanically excavated by using an excavator (a heavy machinery of over 10 tons) to the depth of 20 30 cm from the soil surface in March 2012. In our study, mechanical excavation was adopted as a treatment method not only to remove the mature stands which support other juvenile stands but also to form deep water environment, possibly hindering stolonization of $P$. japonicus. (3) We planted Schoenoplectiella mucronata (L.) J.Jung \& H.K.Choi as an alternative vegetational unit right after the excavation to interfere with re-stolonization of $P$. japonicus. In addition, Schoenoplectiella (Scirpus) spp. are considered as preferable habitats for scarlet pygmy dragonfly, which is an endangered species in Korea (Yoon et al. 2010, 2011).

\section{Follow-up monitoring}

We have surveyed the vegetation cover of the study site at the end of the growing season (early September) from 2008 to 2012 and 2017 to monitor the changes in the vegetation cover. All of wetland plant species of $>1 \mathrm{~m}^{2}$ in area were included as vegetation units in the survey. In addition, flora and number of wetland plant species in the study site in 2017 were investigated to compare with those in 2010 as results of the treatment.

\section{Results}

\section{Changes in vegetation cover}

During the monitoring period, a total of six wetland species were included as vegetational units: P. japonicus, Eleocharis kuroguwai Ohwi, Typha orientalis C. Presl., S. mucronata, Trapa japonica Flerow, and Schoenoplectus tabernaemontani (C.C.Gmel.) Palla (Fig. 1). The sum of vegetation covers (\%) had increased continuously from 2008 to 2011 . The greater part of the site (97\%) was covered by wetland plants, and approximately a half of it was occupied by $P$. japonicus in 2011 . The vegetational cover of $P$. japonicus had increased gradually from 2008 to 2010 (from 34 to $46 \%$ ) despite that the hand-clipped area of $P$. japonica had not been restored during the monitoring period (Fig. 1).

After the excavation of $P$. japonicus in September 2012, the sum of vegetation covers decreased from 97 to $80 \%$ as the cover of $P$. japonicus declined from 43 to $16 \%$. The vegetation cover of $S$. mucronata increased by two-folds (10 to $20 \%$ ) as the result of the planting of alterative vegetational unit. On the other hand, T. orientalis and E. kuroguwai did not show much changes in the vegetation cover by the treatment (Fig. 2).

The vegetation cover of $P$. japonicus had increased slightly from 16 to $21 \%$, whereas the sum of vegetation covers in the study site had increased from 80 to $98 \%$ for 5 years (2012 2017). In particular, S. mucronata occupied almost a half of the study site $(41 \%)$ instead of $P$. japonicus in September 2017. The vegetation cover of $T$. orientalis increased from 21 to 29\%, whereas that of E. kuroguwai sharply decreased from 23 to $7 \%$ (Fig. 2).

\section{Flora and number of wetland plant species}

Flora of the study site in 2017 differed from that in 2010. Four wetland species disappeared: Nymphaea tetragona Georgi, Ottelia alismoides (L.) Pers., Sagittaria aginashii Makino, and Salvinia natans (L.) All.. On the other hand, 13 wetland species appeared: Aeschynomene indica L., Ambrosia artemisiifolia L., Bidens frondosa L., Echinochloa crus-galli (L.) P.Beauv., Hypericum japonicum Thunb., Isachne globosa (Thunb.) Kuntze, Lemna aequinoctialis Welw., Polygonum muricatum Meisn., Polygonum thunbergii Siebold \& Zucc., Salix chaenomeloides Kimura, S. tabernaemontani, T. japonica, and Lindernia micrantha D. Don. The number of wetland plant species of the study site in 2017 increased from 16 to 25 by the shift in species composition when compared with that in 2010 (Table 1).

\section{Discussion}

Phragmites japonicus is one of the major vegetational units of wetland ecosystems in Asian countries. In particular, $P$. japonicus plays an important role as a pioneer, which helps other plant species to settle by making dense roots trapping floating-sediments (Choe and Kim 1999; Asaeda et al. 2011). Numerous and wide-spreading stolons with dense roots of $P$. japonicus physically function as stable aggregates under lotic conditions. In addition, high capacity in nutrient uptake of dense roots on many stolons could also contribute to the rapid growth and occupation of $P$. japonicus in lentic conditions (Hong et al. 2012, 2014). P. japonicus can grow less than $2 \mathrm{~m}$ in height under lotic and oligotrophic conditions, whereas $P$. japonicus can grow higher than $3 \mathrm{~m}$ and expand more than $10 \mathrm{~m} /$ year in lentic wetlands as shown in our monitoring (Hong et al. 2012). 


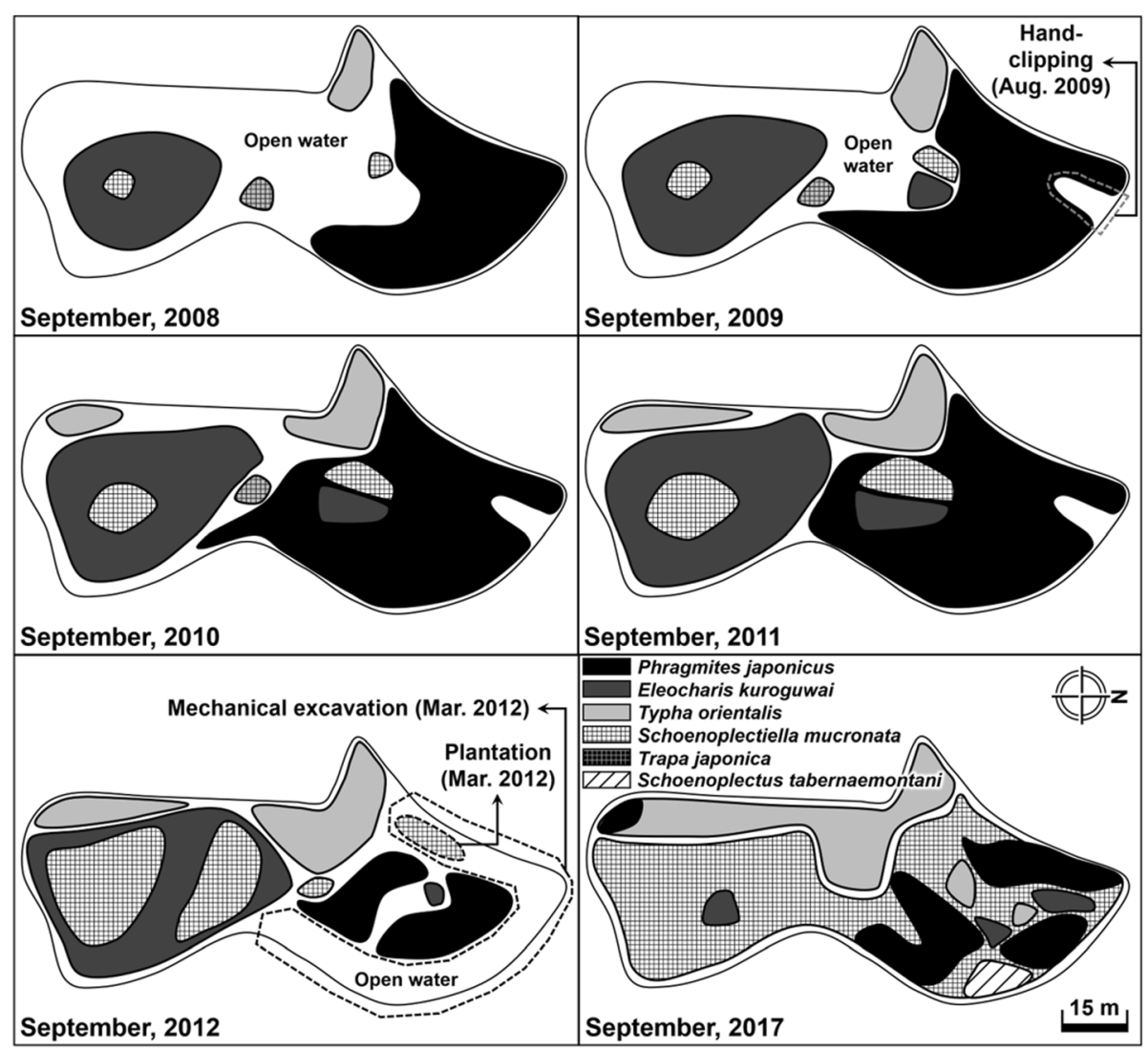

Fig. 1 Vegetation map of the study site during the monitoring period

In lotic wetlands, vigorousness of $P$. japonicus can be used practically such as bed stabilization and water purification (Choe and Kim 1999; Hong et al. 2014). On the other hand, it may affect lentic wetlands as a threat. Monotypic occupation by $P$. japonicus via rapid stolonization in lentic wetlands could decrease biodiversity

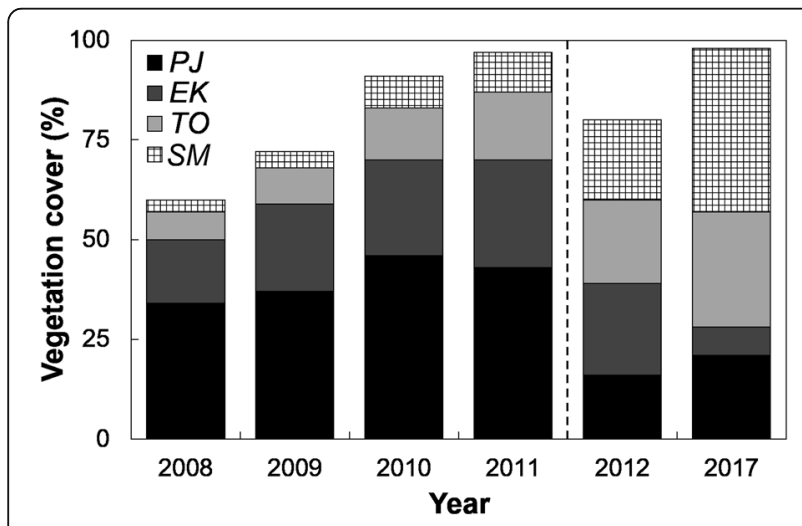

Fig. 2 Vegetational changes of major species in the study site during the monitoring period. $P J=$ Phragmites japonicus, EK = Eleocharis kuroguwai, TO = Typha orientalis, SM = Schoenoplectiella mucronata. The dotted line on the figure divides the results of vegetation cover into before and after the treatment (mechanical excavation and plantation in March 2012) diminishing the value of wetland ecosystems (Hong et al. 2012; Yang and Kim 2016, 2018). Decreased plant species diversity means the loss of habitats, and it can be a more severe problem to the endangered. In addition to the habitats, standing litter of $P$. japonicus could also decrease the area of open-water surface which is an essential environmental factor for the dragonfly species to perch (Tsubaki et al. 1994).

Not only to control $P$. japonicus in lentic wetlands, but also to conserve the habitat of the endangered dragonfly species, we applied three kinds of treatment (hand-clipping, mechanical excavating, and mechanical excavating and additional planting) to the study site and have monitored vegetational changes as the results of the treatments. Hand-clipping worked well in old dense area of $P$. japonicus. There was no shoot emerging in the clipped area, and this might come from the disability of this plant to make stolon in old dense area (Hong et al. 2012). Although the territory of $P$. japonicus seemed to be widened rapidly by stolonization during the growing season, we found that the stolonization worked well only in shallow and non-vegetated areas based on the territory of $P$. japonicus in the following year. Thus, we expected that deep water (natural or by excavation) and established vegetation would interrupt stolonization 
Table 1 Flora and number of wetland plant species in the study site before and after the treatment

\begin{tabular}{|c|c|c|}
\hline Scientific name & $\begin{array}{l}\text { Before treatment }{ }^{\mathrm{a}} \\
(2010)\end{array}$ & $\begin{array}{l}\text { After treatment } \\
(2017)\end{array}$ \\
\hline Aeschynomene indica $\mathrm{L}$. & & $\mathrm{O}$ \\
\hline Ambrosia artemisiifolia L. & & $\mathrm{O}$ \\
\hline Bidens frondosa $\mathrm{L}$. & & $\mathrm{O}$ \\
\hline Blyxa aubertii Rich. & $\mathrm{O}$ & $\mathrm{O}$ \\
\hline Echinochloa crus-galli (L.) P.Beauv. & & $\mathrm{O}$ \\
\hline Eleocharis kuroguwai Ohwi & O & O \\
\hline Hydrilla verticillata (L.f.) Royle & $\mathrm{O}$ & $\mathrm{O}$ \\
\hline Hypericum japonicum Thunb. & & $\mathrm{O}$ \\
\hline Isachne globosa (Thunb.) Kuntze & & $\mathrm{O}$ \\
\hline Juncus effusus L. & O & $\mathrm{O}$ \\
\hline Lemna aequinoctialis Welw. & & $\mathrm{O}$ \\
\hline Lindernia micrantha D. Don & & $\mathrm{O}$ \\
\hline $\begin{array}{l}\text { Monochoria vaginalis } \\
\text { (Burm.f.) C.Presl }\end{array}$ & O & $\mathrm{O}$ \\
\hline $\begin{array}{l}\text { Murdannia keisak (Hassk.) Hand.- } \\
\text { Mazz. }\end{array}$ & O & $\mathrm{O}$ \\
\hline Nymphaea tetragona Georgi & O & \\
\hline Ottelia alismoides (L.) Pers. & O & \\
\hline Polygonum muricatum Meisn. & & $\mathrm{O}$ \\
\hline $\begin{array}{l}\text { Polygonum thunbergii Siebold } \\
\text { \& Zucc. }\end{array}$ & & $\mathrm{O}$ \\
\hline Phragmites japonicus Steud. & $\mathrm{O}$ & $\mathrm{O}$ \\
\hline Potamogeton distinctus A.Benn. & O & $\mathrm{O}$ \\
\hline Sagittaria aginashii Makino & O & \\
\hline Salix chaenomeloides Kimura & & $\mathrm{O}$ \\
\hline Salvinia natans (L.) All. & O & \\
\hline $\begin{array}{l}\text { Schoenoplectus tabernaemontani } \\
\text { (C.C.Gmel.) Palla }\end{array}$ & & $\mathrm{O}$ \\
\hline $\begin{array}{l}\text { Schoenoplectiella mucronata (L.) } \\
\text { J.Jung \& H.K.Choi }\end{array}$ & $\mathrm{O}$ & O \\
\hline Spirodela polyrrhiza (L.) Schleid. & O & $\mathrm{O}$ \\
\hline Trapa japonica Flerow & & $\mathrm{O}$ \\
\hline Trapa natans L. & O & $\mathrm{O}$ \\
\hline Typha orientalis C.Presl & O & $\mathrm{O}$ \\
\hline No. of wetland plant species & 16 & 25 \\
\hline
\end{tabular}

${ }^{a}$ Data from Hong et al. (2012)

process which needs to root in bottom layer of wetland (Byun et al. 2008; Hong et al. 2012). As we expected, deep water and vegetation cover via applying our treatments seemed to effectively disturb the expansion of $P$. japonicus in the study site. In particular, planting of Schoenoplectiella spp. as an alternative vegetational unit instead of $P$. japonicus appeared to determine the change of dominant species of the study site from $P$. japonicus to $S$. mucronata.
During the monitoring period of 10 years, seed establishment of $P$. japonicus has not been observed (a new patch of $P$. japonicus within T. orientalis in 2017 was also formed by stolonization). It appeared likely that $P$. japonicus widened its territory by expanding stolons only in our site. Unlike $P$. australis which makes underground rhizomes for local territory expansion, $P$. japonicus produces creeping stolons in which aerenchyma tissues develop, making stolons likely to float in water layer (Lenssen et al. 2004; Yang et al. 2011). Thus, hand removal of aerial stolons before rooting in the growing season could also be a cost-effective and non-destructive method in addition to the hand-clipping of aboveground shoots that was verified as an effective treatment method for the control of $P$. japonicus via our monitoring.

Abandoned paddy fields (terraces) in mountainous areas are increasing in number particularly in Asian countries because of their low accessibility and economic value. In these days, they are also gaining recognition as valuable wetlands for wildlife (Kim et al. 2010; Park et al. 2013; Cho et al. 2018). However, those lentic wetlands with relatively monotonous topography and landscape are likely to be occupied by strong competitors such as $P$. japonicus which may result in eventually diminished biodiversity of wetland ecosystems. To conserve abandoned paddy fields as valuable lentic wetlands for wildlife from monotypic occupation by $P$. japonicus, we recommend the methods of treatment as follows: (1) regular removal of aboveground shoots including aerial stolons by hand-clipping at growing season (Tanaka et al. 2017), (2) mechanical excavation of mature stands when the great part of the wetland is already occupied since mature stands do not make stolons, which are essential for P. japonicus to expand (Hong et al. 2012), and (3) subsequent planting using alternative vegetational unit such as $S$. mucronata. In our study, the planting after the excavation could interrupt $P$. japonicus to occupy and support the target species such as $N$. pygmaea to thrive particularly in abandoned paddy fields (Kim et al. 2010).

Funding

This work was supported by Basic Science Research Program through the National Research Foundation of Korea (NRF) funded by the Ministry of Education (NRF-2015R1D1A1A01057373), the National Research Foundation of Korea (NRF) grant funded by the Korea government (MSIT) (NRF2018R1A2B2002267), and the Korea Ministry of Environment (MOE) as "public technology program based on Environmental Policy."

Availability of data and materials

The datasets during and/or analyzed during the current study are available from the corresponding author on reasonable request.

\section{Authors' contributions}

MGH designed the study and wrote the manuscript draft. HJP and BEN participated in the field works. JGK conceived the study and edited the manuscript. All authors read and approved the final manuscript.

Ethics approval

Not applicable 


\section{Consent for publication}

Not applicable

\section{Competing interests}

The authors declare that they have no competing interests.

\section{Publisher's Note}

Springer Nature remains neutral with regard to jurisdictional claims in published maps and institutional affiliations.

Received: 3 September 2018 Accepted: 8 October 2018

Published online: 19 October 2018

\section{References}

Asaeda T, Baniya MB, Rashid MH. Effect of floods on the growth of Phragmites japonica on the sediment bar of regulated rivers: a modelling approach. Int J River Basin Manag. 2011;9:211-20.

Asaeda T, Siong K, Kawashima T, Sakamoto K. Growth of Phragmites japonica on a sandbar of regulated river: morphological adaptation of the plant to low water and nutrient availability in the substrate. River Res Appl. 2009;25:874-91.

Byun C, Kwon GJ, Lee D, Wojdak JM, Kim JG. Ecological assessment of plant succession and water quality in abandoned rice fields. J Ecol Field Biol. 2008; 31:213-23

Cho Y-C, Lee S-M, Lee C-S. Floristic composition and species richness of soil seed bank in three abandoned rice paddies along a seral gradient in Gwangneung Forest Biosphere Reserve, South Korea. J Ecol Environ. 2018;42:12.

Choe GC, Kim NC. Study on the revegetation methods of Phragmites japonica, Miscanthus sacchariflorus, Themeda triandra and Pennisetum alopecuroides for the rehabilitation of close-to-nature river. J Korean Soc Environ Restor Technnol. 1999;2:70-7.

Chu H, Cho WK, Jo Y, Kim W-I, Rim Y, Kim J-Y. Identification of natural hybrids in Korean Phragmites using haplotype and genotype analyses. Plant Syst Evol. 2011:293:247-53

Chun SH, Hyun JY, Choi JK. A study on the distribution patterns of Salix gracilistyla and Phragmites japonica communities according to microlandforms and substrates of the stream corridor. J Korean Institute Landscape Architect. 1999;27:58-68.

Hong MG, Kim JG. Role and effects of winter buds and rhizome morphology on the survival and growth of common reed (Phragmites australis). Paddy Water Environ. 2014;12(Suppl 1):S203-9.

Hong MG, Nam JM, Kim JG. Occupational strategy of runner reed (Phragmites japonica Steud.): change of growth patterns with developmental aging. Aquat Bot. 2012;97:30-4.

Hong MG, Son CY, Kim JG. Effects of interspecific competition on the growth and competitiveness of five emergent macrophytes in a constructed lentic wetland. Paddy Water Environ. 2014;12(Suppl 1):S193-202.

Kim DG, Yum JW, Yoon TJ, Bae YJ. Life history of an endangered dragonfly, Nannophya pygmaea Rambur, in Korea (Anisoptera: Libellulidae). Odonatologica. 2010;39:39-46.

Kim Y-H, Kim J-H. Genetic variations and relationships of Phragmites japonica and $P$. communis according to water environment change. Korean J Plant Resour. 2009;22:152-8

Lenssen JPM, Kleunen MV, Fischer M, Kroon HD. Local adaptation of the clonal plant Ranunculus reptans to flooding along a small-scale gradient. J Ecol. 2004;92:696-706

Park HJ, Nam BE, Hong MG, Kim JG. Slope and soil nutrients can explain the distribution of Phragmites australis and P. japonica in riparian wetlands. River Res Appl. 2018. https://doi.org/10.1002/rra.3350.

Park J, Hong MG, Kim JG. Relationship between early development of plant community and environmental condition in abandoned paddy terraces at mountainous valleys in Korea. J Ecol Environ. 2013;36:131-40.

Tanaka TST, Irbis C, Kumagai H, Wang P, Li K, Inamura T. Effect of Phragmites japonicus harvest frequency and timing on dry matter yield and nutritive value. J Environ Manag. 2017;187:436-43.

Tsubaki Y, Michael TSJ, Tomohiro O. Recopulation and post-copulatory mate guarding increase immediate female reproductive output in the dragonfly Nannophya pygmaea Rambur. Behav Ecol Sociobiol. 1994;35:219-25.

Yang C, Zhang X, Zhou C, Seago JL Jr. Root and stem anatomy and histochemistry of four grasses from the Jianghan Floodplain along the Yangtze River, China. Flora. 2011;206:653-61.
Yang YY, Kim JG. The optimal balance between sexual and asexual reproduction in variable environments: a systematic review. J Ecol Environ. 2016;40:12.

Yang YY, Kim JG. Correction to: the optimal balance between sexual and asexual reproduction in variable environments: a systematic review. J Ecol Environ. 2018;42:6.

Yoon J, Kim H, Nam JM, Kim JG. Optimal environmental range for Juncus effusus, an important plant species in an endangered insect species (Nannopya pygmaea) habitat in Korea. J Ecol Field Biol. 2011;34:223-35.

Yoon J, Nam JM, Kim H, Bae YJ, Kim JG. Nannophya pygmaea (Odonata: Libellulidae), an endangered dragonfly in Korea, prefers abandoned paddy fields in the early seral stage. Environ Entomol. 2010;39:278-85.
Ready to submit your research? Choose BMC and benefit from:

- fast, convenient online submission

- thorough peer review by experienced researchers in your field

- rapid publication on acceptance

- support for research data, including large and complex data types

- gold Open Access which fosters wider collaboration and increased citations

- maximum visibility for your research: over $100 \mathrm{M}$ website views per year

At $\mathrm{BMC}$, research is always in progress.

Learn more biomedcentral.com/submissions 